\title{
Pakistan's Response to COVID-19 Pandemic and Efficacy of Quarantine and Partial Lockdown: A Review
}

\author{
Mohammad Nafees ${ }^{1 \star}$, Farukh Khan ${ }^{2}$
}

${ }^{1}$ Department of Environmental Sciences, University of Peshawar, PAKISTAN

${ }^{2}$ CEOS University, Peshawar, PAKISTAN

*Corresponding Author: nafees@uop.edu.pk

Citation: Nafees M, Khan F. Pakistan's Response to COVID-19 Pandemic and Efficacy of Quarantine and Partial Lockdown: A Review. Electron J Gen Med. 2020;17(6):em240. https://doi.org/10.29333/ejgm/7951

\section{ARTICLE INFO}

Received: 3 Apr. 2020

Accepted: 5 Apr. 2020

\begin{abstract}
Pakistan, being as a neighbor country of China and Iran was vulnerable most to COVID-19 pandemic. During receiving Pakistani pilgrims from Iran, Pakistani government reacted toward the spread of COVID-19 after report of first COVID-19 case on $25^{\text {th }}$ of February, 2020. Quarantine facilities were arranged with delay and were the main cause of epidemic in Pakistan. Out of the total COVID-19 cases 78 percent cases were linked with the visitors coning from Iran. Simultaneously, Pakistan announced closure of all education institutions with a partial lockdown across the country. This badly affected the labor community. Due to lack of record/ database, Pakistani government faced problem in supporting the labor community. The partial lockdown was effective to some extent and the epidemic was brought under control. To cope with such pandemic/epidemic situations in future, the various lessons learned have been given as recombinations for the future.
\end{abstract}

Keywords: Coronavirus, pandemic, emergency quarantine, partial lockdown, endemic, self-quarantine

\section{INTRODUCTION}

The outbreak of coronavirus was not new to the world. It was observed in various parts of the world in the past (1). It was discovered in 1960. Coronavirus caused upper and lower respiratory problems in human and was termed as severe acute respiratory syndrome, abbreviated as SARS (2). The first outbreak of coronavirus related infection was documented in 2002-03. That affected 29 countries of Asia, Europe, North and South America. About eight thousand cases were identified with 9.5\% fatalities (3). Studies conducted in 2010-15 revealed that coronavirus was found in both, animals and humans being. Although it was lethal, but till now no vaccine is available. Therefore, preventative strategy was/is recommended against the outbreak of corona virus, such as change in eating habits, monitoring and surveillances (4). Recently, Chloroquine was also tried, but not very effective to treat COVID-19 (5). In 2007 a detail study was conducted about infectious viral diseases in Pakistan. It was suggested that Pakistan is facing various problems, such as flood, earthquake, epidemic of various viral diseases (Polio, dengue, and hepatitis). Therefore, Pakistan government is required to go for a comprehensive health policy of preventative nature (6).

Quarantine is one historical preventative measure and has a key role in prevention of epidemic and pandemic. It is simply isolation of suspected patient for a particular time period $(7,8)$. During this isolation, if a person develops symptoms of a particular disease, $s /$ he is transferred to hospital for further treatment. If $\mathrm{s} /$ he developed no such symptoms, $\mathrm{s} /$ he is set free (9). Quarantine period is different for differ diseases.
Incubation period of corona virus is 14 days, and was suggested as quarantine period for coronavirus virus $(10,11)$.

\section{METHOD AND APPROACH}

This was a desktop study. Most of the informations were collected from print, electronic and social media.

\section{LIMITATION OF THE STUDY}

Due to partial lockdown it was not possible to locate COVID-19 patient and contact them.

\section{RESULTS AND DISCUSSION}

In Pakistan first case of COVID-19 was reported on 25th of February 2020. The number of COVID-19 reached to 1865 on 31 st March with 25 deaths (12). The WHO reports revealed that the number of new cases is toward increase. In comparison with other countries, especially the neighbor (Iran and China), the number of COVID-19 cases are very less (Figure 1 ).

First COVID-19 case was reported on 25th of February and First death was reported on 29th March. During that period no one believed on coronavirus. One thing is clear that in comparison of the neighboring countries (China and Iran), situation of Pakistan is not worst. 


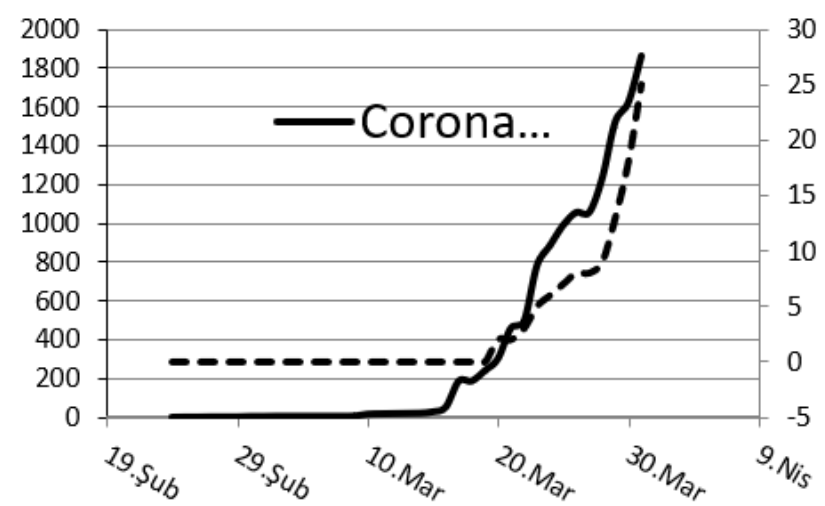

Figure 1. COVID-19 cases during 25 February and 31 March 2020 (Source: WHO reports No. 35-71, 2020)

Table 1. The province-wise breakup of the total number of cases (30March 2020)

\begin{tabular}{cccc}
\hline S No & Province & Case & Deaths \\
\hline 1 & Sindh & 566 & 8 \\
\hline 2 & Punjab: & 638 & 6 \\
\hline 3 & Khyber Pakhtunkhwa: & 217 & 5 \\
\hline 4 & Baluchistan: & 144 & 1 \\
\hline 5 & Islamabad Capital Territory: & 51 & 0 \\
\hline 6 & Gilgit-Baltistan: & 141 & 0 \\
\hline 7 & Azad Jamu and Kashmir & 6 & 0 \\
\hline 8 & Total confirmed cases: & 1,763 & 22 \\
\hline
\end{tabular}

Source: GeoTV, 30 March 2020

The province wise record revealed that maximum cases were observed in Punjab province, the populated most province of Pakistan (Table 1). Till 30 March, number of deaths was comparatively less, but due to continuous increase, became a problem.

Statistics revealed that Pakistan has attained and maintained minimum level of COVID-19 cases. Question arises, how Pakistan received coronavirus? First case in China was reported on 10 January 2020 followed by Iran on 18 February 2020. During this period of time, Pakistan was completely silent, and no preventive measure was adapted. When first case was reported, Pakistan first focused on Pak- Iran border and international flights. The various measures and associated of Pakistan could be highlighted as below.

\section{ESTABLISHMENT QUARANTINE HOUSE}

Government of Pakistan has set quarantine house at borders as well as in various cities. Simultaneously, the government has decided to lockdown major cities for more than one-month duration. In this way, the whole country was put into self-quarantine as practiced by other countries, such as china and Malawi also (13). But the government has offered no facility to keep the citizen inside their houses. For basic needs and daily requirements, such as food and medicines, they were allowed to go outside of their houses. This is how; some shops were allowed to keep open. These include vegetables, general store, and medical stores. Some business and shops were completely closed, such as hotels, weeding hall, barber shops and beauty parlors.

Pilgrims from Iran was one big problem for Pakistan. In the first week of March more than 3000 pilgrimage were received and were kept limited to Taftan. When the number of pilgrims
Table 2. Pilgrims received at Taftan

\begin{tabular}{ccc}
\hline S No & Province/Region & No. of Pilgrims \\
\hline 1 & Baluchistan/Taftan & 427 \\
\hline 2 & Baluchistan/Quetta (Main Ghundi) & 532 \\
\hline 3 & Sindh/Sukker & 1059 \\
\hline 4 & Sindh/DG Khan & 782 \\
\hline 5 & Khyber Pakhtunkhwa / DI Khan & 269 \\
\hline 6 & Punjab/ Multan & 1247 \\
\hline 7 & Azad Kashmir Mirpur: & 13 \\
\hline 8 & Galgit & 493 \\
\hline Source: Aljazeera TV (9)
\end{tabular}

exceeded 6000 , it became difficult to be accommodated in quarantine center at Taftan. Pakistan was not expecting such huge number and was not prepared for this. Initially it was decided to place them at Taftan for 14 days quarantine. But the pilgrims were not cooperating and were with attempts to escape from the quarantine center (14).

On 26 March it was decided to hand over the pilgrims to their respective provinces from where they belonged. In this way 4596 were handed over to provincial administration. They were placed in various quarantine centers (Table 2).

In most newspapers and electronic media this handing over and distribution of Pilgrims was highlighted as a reason for cultivation and spread out of COVID-19 in Pakistan. According to Aljazeera TV, Taftan was the center of epidemic in Pakistan. By reviewing various videos clips uploaded by different people, the following problems were identified.

1. Unhygienic conditions

2. Non availability of doctors

3. Non availability of medicine

4. Capacity

5. Availability of water and food

Some quarantine centers were well equipped. For example, at Multan the quarantine center was set in Industrial Estate for pilgrims returning from Iran. 1247 pilgrims were kept against the available capacity of 3000 . Pilgrims at Sukkur were kept in Labor Colony for quarantine. Residence of the colony came out on the streets with protest against the government for the said quarantine center. As a whole, the quarantine arrangement was not satisfactory. This is why it was part of hot news on social and electronic media. Therefore, pilgrims from Iran were blamed for the growing epidemic of COVID-19. According to the spokesman from health ministry 78.2 cases were trace back to the pilgrims coming from Iran (15).

\section{CLOSURE OF EDUCATION INSTITUTION}

To avoid quick spread of coronavirus, all school, colleges and universities were closed on 13 March 2020 throughout the country. Initially this act of government was criticized for the reasons that no alternate arrangements were made to save time of the students. Such as online classes, quiz program, reading materials, assignment etc. Later on, with the passage of time, the infection was spread out rapidly across the globe as well as in Pakistan. It was proved that this closure was justified and was a good decision.

According to first announcements, all educational institutions were closed till 31 March. Later on, it was extended till 31 May 2020, with a mentioning that this break will be counted as summer vacation. In most parts of Pakistan, due to 
hot summer, education institutes observed summer vacation during Jun and August. This year all the students will attend classes in hot most months of the year. For some people this may be a simple matter, but technically it is not that sound. All the schools, colleges and universities are not equipped to handle temperature above $40 \mathrm{OC}$ and will be a real problem, especially for the small kids. Besides, there is usually outbreak of summer diseases like diarrhea, and dengue $(4,16)$. Pakistan may need to arrange a separate session of vaccinating for seasonal disease along with a separate program to beat high temperature.

\section{DAILY WAGE LABOR}

Daily wage labor is the most vulnerable segment of our population. At present, Pakistan has a labor force of 72.5 million. 9.5 million are above 50 years age and 63 million are above 15 years age working in different sectors. Out of this total, 7 million are daily wage worker and 3.6 million are unemployed (17). Being as a developing country, it was not possible for the government of Pakistan to reach every daily wage labor for appropriate support for their daily needs. Initially there was partial lockdown in Pakistan. The aim of partial lockdown was to avoid unnecessary interaction and mobility. Partial lockdown was good for daily wage labor. They could go to their workplace.

In the second phase major cities were locked down. Again, it cannot be called complete lockdown, as someone can go outside for the purchase of various items of daily importance. Major markets, hotels and restaurants were closed completely. After city level lockdown, Pakistan (Federal Government) has announced a relief package of 3,000 rupees per month for 7 million daily wage workers (11). But there was no proper record/ database for such labor and was difficult to differentiate between labor and daily wage labor and help out the right person. Besides this, Rs. 3000/- was not enough to meet monthly expenditures. According to Haq et al 2008, monthly food expenses of an average household size of five members is ranged from Rs. 14000 to 17000 (18).

As per latest estimate, due to COVID-19, about 12.3 to 18.53 million may lose their emoluments. At present the monthly loss is about 22 billion. If the lock down continued, the monthly loss may go up to 260.9 billion per month with a total collapse and irreparable loss to labor force of Pakistan (19).

The COVID-19 episode is continued, and Pakistan still has a long distance to go. Pakistan has to take care of its population in general and its labor force in particular. Pakistan is required to take the religious institution in confidence, use the government machinery for better planning in the coming days.

\section{CONCLUSIONS}

Due to limited resources, like other developing countries, Pakistan was not in a position to handles such fast-growing pandemic effectively. No one was expecting Pakistan to handle this pandemic efficiently. The various developments revealed that the control over COVID-19 were promising. Therefore, the various acts of Pakistan were appreciable and got control over the spread of VOVID-19 to a big extent.

COVID-19 is/was new to the world; it affected poor and rich countries equally. Here is a lesson for the future that developing countries seems more vulnerable as compared to developed world due to the following reasons.

1. Arrangement and management of quality quarantine facility

2. Occupational safety measures for doctors and other health workers

3. Awareness and education of common persons

4. Handling of daily wage labor and other poor segments of a society

5. Availability of preventive measures in terms of sanitizer and good personal hygiene

6. On time availability of first aid

7. Special transport facility for COVID-19 patients and dead bodies.

8. Availability of on time treatment in hospitals.

\section{LESSONS LEARNED FOR THE FUTURE}

On the basis of the above factors, poor countries, like Pakistan are/were more vulnerable and affected negatively. The following are few recommendations, as lessons learned for Pakistan as well as other developing countries.

1. Must construct quarantine facilities on all exist and entrance with the neighboring countries.

2. Pakistan should establish quarantine facilities at provincial level in all provincial capital cities, Karachi, Quetta, Lahore and Peshawar.

3. We must initiate, at least at university level, online classes as future strategy to avoid break in academic session during epidemic.

4. Each country must keep a database for all sort of labor. In this way the government of Pakistan can reach to poor labor on time for support.

\section{ACKNOWLEDGEMENTS}

We are very thankful to the World Health Organization and Government of Pakistan for all efforts and regular and on time information provided on their web sites. We are also thankful for the responsible reporting of national and international electronic and print media for on time reporting. Special thanks goes to all health care workers and police who are on the frontlines of the pandemic/epidemic. We hope that this report will be helpful for the young researcher and policy maker in future.

\section{REFERENCES}

1. Minh Duc N, Duc Ha H, Anh Tuan T, Lien Bang MT, Hong Duc P, Minh Thong P. From First COVID-19 Case to Current Outbreak: A Vietnamese Report. Electron J Gen Med. 2020;17(4):em208. https://doi.org/10.29333/ejgm/7867 
2. Malik YS, Sircar S, Bhat S, Sharun K, et al. Emerging novel coronavirus (2019-nVoV)- current scenario, evolutionary perspective based on genome analhysis and recent developments. Veterinary quarterly, 2020;40(1):68-76. https://doi.org/10.1080/01652176.2020.1727993 PMid:32036774 PMCid:PMC7054940

3. Kahn JS, McIntosh K. History and recent advances in coronavirus discovery. The Pediatric infectious disease journal, 2005;24(11):S223-S227. https://doi.org/10.1097/ 01.inf.0000188166.17324.60 PMid:16378050

4. Graham, R. L., Donaldson, E. F., \& Baric, R. S. (2013). A decade after SARS: strategies for controlling emerging coronaviruses. Nature Reviews Microbiology, 2013;11(12):836-48. https://doi.org/10.1038/nrmicro3143 PMid:24217413 PMCid:PMC5147543

5. Aljofan M, Gaipov A. Chloroquine and COVID-19: A Light at the End of the Tunnel, or is it Another Train?. Electron J Gen Med. 2020;17(4):em207. https://doi.org/10.29333/ejgm/ 7863

6. Khalil AT, Ali M, Tanveer F, Ovais M, Idrees M, Shinwari ZK, Hollenbeck JE. Emerging viral infections in Pakistan: issues, concerns, and future prospects. Health security, 2017;15(3):268-81. https://doi.org/10.1089/hs.2016.0072 PMid:28636447

7. Manuell ME, Cukor J. Mother Nature versus human nature: public compliance with evacuation and quarantine. Disasters, 2011;35(2):417-42. https://doi.org/10.1111/ j.1467-7717.2010.01219.x PMid:21073672

8. Wilder-Smith A, Freedman DO. Isolation, quarantine, and social distancing and community containment: pivotal role for old-style public health measures in the novel coronavirus (2019-nCoV) outbreak. Journal of travel medicine. 2020;27(2):20. https://doi.org/10.1093/ jtm/taaa020 PMid:32052841 PMCid:PMC7107565

9. Benjamin GC, Stratton K, Sivitz LB. (Eds.). Quarantine stations at ports of entry: protecting the public's health. National Academies Press. 2006.

10. Fielding CL, Higgins JK, Higgins JC, Mclntosh S, Scott E, Giannitti F, Pusterla N. Disease associated with equine coronavirus infection and high case fatality rate. Journal of veterinary internal medicine, 2015;29(1):307-10. https://doi.org/10.1111/jvim.12480 PMid:25319406 PMCid:PMC4858071
11. Backer JA, Klinkenberg D, Wallinga J. Incubation period of 2019 novel coronavirus (2019-nCoV) infections among travellers from Wuhan, China, 20-28 January 2020. Eurosurveillance, 2020;25(5):2000062. https://doi.org/ 10.2807/1560-7917.ES.2020.25.5.2000062 PMid:32046819 PMCid:PMC7014672

12. World Health Organization. (2020). Considerations for quarantine of individuals in the context of containment for coronavirus disease (COVID-19): interim guidance, 19 March 2020 (No. WHO/2019-nCoV/IHR Quarantine/2020.2). World Health Organization.

13. Munthali GNC, Xuelian W. Covid-19 Outbreak on Malawi Perspective. Electron J Gen Med. 2020;17(4):em210. https://doi.org/10.29333/ejgm/7871

14. Asad Hashim. Pakistani doctors decry lack of supplies as lockdown looms. Aljazeera TV, dated 23 March, 2020. Available at: https://www.aljazeera.com/amp/news/2020/ 03/pakistani-doctors-decry-lack-supplies-lockdowndebate-rages-200323110940130.html

15. The News International, 2020.78pc of confirmed Corona cases have travel history of Iran: Dr. Zafar Mirza. Available at: https://www.thenews.com.pk/print/634172-78pc-ofconfirmed-corona-cases-have-travel-history-of-iran-drzafar-mirza (Accessed 1 April 2020).

16. Saqlain M, Munir MM, Ahmed A, Tahir AH, Kamran S. Is Pakistan prepared to tackle the coronavirus epidemic? Drugs \& Therapy Perspectives, 2020;1-2. https://doi.org/10.1007/s40267-020-00721-1 PMid:32218652 PMCid:PMC7095264

17. Ahmad I. COVID-19 and Labour Market. Centre for Labour research. 2020. Available at: https://clr.org.pk/covid-19labour-market/

18. Haq ZU, Nazli H, Meilke K. Implications of high food prices for poverty in Pakistan. Agricultural Economics, 2008;39:477-84. https://doi.org/10.1111/j.1574-0862.2008. 00353.x

19. Haider M. Forecast of COVID-19: 'Pakistan may face $12.3 \mathrm{~m}$ to $18.53 \mathrm{~m}$ lay offs'. The daily news, international. Dated 24 March 2020. Available at: https://www.thenews.com.pk/ print/633754-forecast-of-covid-19-pakistan-may-face-123m-to-18-53m-lay-offs 